CONSERVATION

BIOLOGY

\section{Assessment of Macrophyte Biological Index for Rivers, and evaluation of physicochemical parameters in the Sakarya River Basin of Turkey}

\author{
Arda Acemi ${ }^{1}$, Halim Aytekin Ergül1', Melih Kayal², \\ Fatih Ekmekçi², and Fazıl Özen ${ }^{1}$
}

'Department of Biology, Faculty of Arts and Sciences, Kocaeli University, 41001, İzmit, Kocaeli, Turkey

${ }^{2}$ Investigating, Planning and Allocations Department,

General Directorate of State Hydraulic Works, 06100, Çankaya, Ankara, Turkey

Address correspondence and requests for materials to Arda Acemi,

arda.acemi@kocaeli.edu.tr

\begin{abstract}
In this study, the Macrophyte Biological Index for Rivers (IBMR) method and physicochemical measurements were used to assess the trophic status of the Sakarya River Basin in Turkey. The most abundant macrophytes were Phragmites australis, Thypa latifolia, Juncus sp., and Paspalum distichum. The IBMR values varied between 6.00 and 13.00 in spring, and between 6.714 and 14.40 in the fall season. The sampling stations, which are under the influence of agricultural runoffs, domestic effluents, and industrial discharges, had hypoxia accompanied by eutrophic and/or hypertrophic conditions at least in one season. The individual trophy levels of the sampling sites in the basin have been assessed as mesotrophic to eutrophic. However, considering the average IBMR value of all stations, the general trophy level of the basin was close to eutrophic. The results indicate that the physicochemical parameters are affected by various effluents discharged to the basin as observed during field studies, and the obtained data would be useful to apply conservation measures.
\end{abstract}

Keywords: ecological quality, eutrophication, IBMR, macrophyte, Sakarya River Basin 0270-8507; Halim Aytekin Ergül, PhD, Associate Professor, orcid.org/0000-00029313-1426; Melih Kayal, Master of Sci. in Engineering, Environmental Engineer, orcid. org/0000-0003-0656-7684; Fatih Ekmekçi, Master of Sci. in Engineering, Environmental Section Manager, orcid.org/0000-0003-23059163; Fazıl Özen, PhD, Head of Department Professor, orcid.org/0000-0001-9293-908X

Manuscript Editor: Evgeny Abakumov, Department of Applied Ecology, Faculty of Biology, Saint Petersburg State University, Saint Petersburg, Russia

Received: July 27, 2020;

Revised: December 7, 2020;

Accepted: December 18, 2020.

Copyright: (c) 2021 Acemi et al. This is an open-access article distributed under the terms of the License Agreement with Saint Petersburg State University, which permits to the authors unrestricted distribution, and self-archiving free of charge.

Funding: This research was funded by the Turkish General Directorate of State Hydraulic Works (DSI) in the framework of the "DSI Capacity Development, and Water Quality Monitoring Project in Sakarya River Basin" during 2017 and 2018.

Ethics statement: This paper does not contain any studies involving human participants or animals performed by any of the authors.

\section{Introduction}

Industrial effluents, urbanization-related wastewater inputs, and excess fertilizer usage in agricultural activities are considered significant sources of increased eutrophication in freshwaters such as rivers, streams, and ponds (Chislock et al., 2013; Khatri and Tyagi, 2015). These factors modify the chemical and physical characteristics of freshwaters, thereby directly affecting the floral and faunal elements (Ceschin et al., 2010). Among these elements, macrophyte species have been used as indicators of ecological quality status in many studies (Haury et al., 2006; Szoszkiewicz et al., 2009; Manera et al., 2014; Özen et al., 2017). The growth, abundance, and association of macrophytes are altered depending on several abiotic factors such as climatic conditions, chemical composition (i.e., macro and microelement concentrations), $\mathrm{pH}$, flow rate, hydrological properties of water, and type of substrate (Lopes et al., 2016). Also, anthropogenic impacts such as leakage of nutrients from agricultural lands can affect macrophyte composition and development (Elo et al., 2018). Therefore, several methods that depend on the evaluation of macrophyte associations and their abundances have been developed to estimate the ecological status of rivers and lakes (Ceschin et al., 2010). The determination of eutrophication levels in rivers is done according to three main methods, namely; Mean Trophic Rank (Dawson et al., 1996), Trophic Index with Macrophytes (Schneider and Melzer, 2003), and Macrophyte Biological Index for Rivers - Indice Biologique 


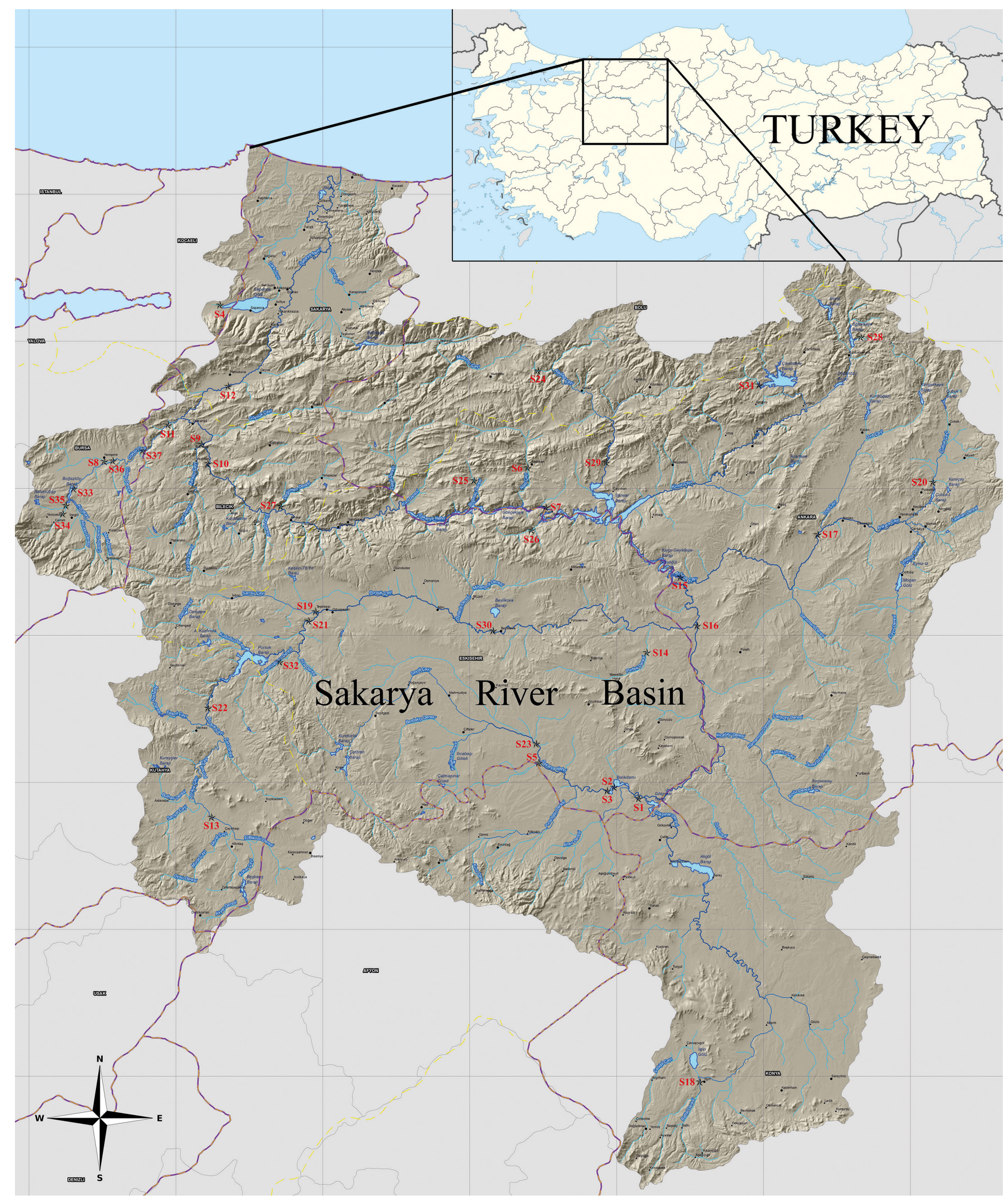

Fig. 1. Map of the Sakarya River Basin showing the sampling stations. The map has been provided by General Directorate of State Hydraulic Works of Turkey (DSI). 
Macrophytique en Rivière (IBMR; Haury et al., 2006). The IBMR method has been officially adopted by several countries including France, where the method was first developed, Italy, Belgium (Wallonia), and Turkey to assess the ecological quality of freshwaters, as per the European Water Framework Directive (European Council 2000) of the European Parliament and the Council (Solimini et al., 2008; Manera et al., 2014).

Turkey's basins have been classified into 25 main sectors for hydrological studies. The Sakarya River Basin is one of Turkey's most significant river basins and is very diverse in terms of agricultural, industrial, and domestic usage. The basin is located in the northwest of the Anatolian Peninsula, having a drainage area of $58160 \mathrm{~km}^{2}$ (DSI, 2016). The rivers in the basin pass through 13 densely urbanized provinces (Eskişehir, Sakarya, Bilecik, Ankara, Bolu, Kütahya, Afyonkarahisar, Konya, Bursa, Kocaeli, Düzce, Çankırı, and Uşak) where many industrial facilities are located (Solak et al., 2020). Thus, monitoring the basin's ecological status is crucial for protecting freshwater sources and nature. To our knowledge, there is no study published in the open literature regarding macrophyte-based evaluation of ecological status, including the IBMR indices, which offers a practical assessment of watercourses in the Sakarya River Basin. Therefore, the aims of the present study are: 1) to assess the general ecological quality of the waterworks and effected factors in the Sakarya River Basin by estimating the trophic status of various sampling points; 2) to compare ecological quality and accompanied physicochemical parameter variations between fall and spring seasons.

\section{Material and methods}

\section{Study Site and Sampling Stations}

The Sakarya River Basin is an individual river (Sakarya River) basin covering about $7 \%$ of Turkey. The total length of the Sakarya River with its tributaries is $720 \mathrm{~km}$. The mean annual rainfall of the basin is estimated at $479 \mathrm{~mm}$, while the total annual rainfall is 32 billion $\mathrm{m}^{3}$. The drainage density of the basin is $0.31 \mathrm{~km} \mathrm{~km}^{-2}$. The basin's mean slope is $18.09 \%$, with a mean altitude of $969 \mathrm{~m}$ (DSI 2016). The sampling was carried out during November 2017 and May 2018 in 37 sampling locations throughout the basin (Fig. 1). Locations and codes of the stations are provided in Table 1.

\section{Macrophyte Sampling Methodology and Species Identification}

The sampling was done by observing macrophytes at rivers for a range of $100 \mathrm{~m}$ (transect). This range was divided into four equal subranges (quadrates) when applicable to enable a homogenous sampling. The macrophyte species were sampled by rake, grapple, or directly
Table 1. Locations of the sampling stations

\begin{tabular}{|c|c|c|c|}
\hline $\begin{array}{c}\text { Station } \\
\text { code }\end{array}$ & Location & $\begin{array}{c}\text { Station } \\
\text { code }\end{array}$ & Location \\
\hline S1 & Eskişehir - Sivrihisar & $S 20$ & Ankara - Altındağ \\
\hline$S 2$ & Eskişehir - Sivrihisar & $S 21$ & Eskişehir - City Center \\
\hline S3 & Eskişehir - Sivrihisar & $S 22$ & Kütahya - City Center \\
\hline S4 & Kocaeli - City Center & S23 & Eskişehir - Sivrihisar \\
\hline S5 & Eskişehir - Sivrihisar & $S 24$ & Bolu - Seben \\
\hline S6 & Ankara - Nallıhan & $S 25$ & Ankara - Nallıhan \\
\hline S7 & Ankara - Nallıhan & $S 26$ & Eskişehir - Mihalıçcık \\
\hline S8 & Bursa - Yenişehir & $S 27$ & Bilecik - İnhisar \\
\hline S9 & Bilecik - City Center & $S 28$ & Ankara - Kızılcahamam \\
\hline S10 & Bilecik - City Center & $S 29$ & Ankara - Nallıhan \\
\hline S11 & Bilecik - Osmaneli & S30 & Eskişehir - Beylikova \\
\hline S12 & Sakarya - Pamukova & S31 & Ankara - Çamlıdere \\
\hline$S 13$ & Kütahya - Altıntaş & S32 & Eskişehir - City Center \\
\hline S14 & Eskişehir - Sivrihisar & S33 & Bursa - İnegöl \\
\hline S15 & Ankara - Polatlı & S34 & Bursa - İnegöl \\
\hline S16 & Ankara - Polatlı & S35 & Bursa - İnegöl \\
\hline S17 & Ankara - Sincan & S36 & Bursa - Yenişehir \\
\hline S18 & Konya - Ilgın & S37 & Bursa - Yenişehir \\
\hline S19 & Eskişehir - City Center & & \\
\hline
\end{tabular}

Locations are given as the names of "province - district".

by hand and then identified according to the proper keys in Flora of Turkey (Davis et al., 1985) and Cook et al.s manual for identification of freshwater macrophyte genera (1974).

\section{Estimation of IBMR}

The IBMR values of the sampling stations were estimated according to the technical norm developed by the French Association for Normalization (AFNOR, 2003). The frequency and coverage of the listed species were estimated according to their visual appearances in the sampling stations. The variations in the IBMR values between fall and spring seasons were compared, and accompanied physicochemical values were evaluated. To enable a more accurate comparison between sampling seasons, we discarded from the IBMR calculation any stations having lesser than three macrophyte species that were not predominant in the river bed (and therefore characterized by very low coverage value at least in one sampling season), as well as stations with a dried waterbed in any sampling season. The changes in the values were discussed in terms of the macrophyte composition 
and anthropogenic factors. The following formula was used to determine IBMR value:

$$
I B M R=\frac{\sum_{i}^{n} E i \times K i \times C S i}{\sum_{i}^{n} E i \times K i},
$$

where CSi is a score of a macrophyte taxon, varying between 0 and 20 depending on tolerance to ammonium, orthophosphate, and heavy organic pollution; Ei indicates the coefficient of ecological amplitude; Ki represents the scale of cover for macrophytes, where $i$ is the number of contributory species, and $\mathrm{n}$ stands for the total number of contributory species (Haury et al., 2006).

The scale of Haury et al. (2006) describes the trophic status of water bodies based on their IBMR values in the following scale decreasing from oligotrophic to hypertrophic: IBMR $>14$, Very good; $14 \geq$ IBMR $>12$, Good; $12 \geq$ IBMR $>10$, Moderate; $10 \geq$ IBMR $>8$, Poor; $8 \geq$ IBMR, Bad.

\section{Physicochemical Measurements}

The $\mathrm{pH}$ values, electrical conductivities $\left(\mu \mathrm{S} \mathrm{cm}^{-1}\right)$, and dissolved oxygen concentrations $\left(\mathrm{mg} \mathrm{L}^{-1}\right)$ of the waters in the stations were measured using a multi-parameter data sonde (Hydrolab-DS5), while flow rates $\left(\mathrm{m}^{3} \mathrm{~s}^{-1}\right)$ were measured through an electronic flow probe (AKIM, Turkey). The measurements were done twice, at the same time as biological sampling.

\section{Statistical analysis}

The Pearson correlation was used to evaluate correlations between two dependent variables at $95 \%$ and $99 \%$ confidence levels. The statistical comparison was applied to the yearly values calculated as the arithmetic mean of the data obtained in both sampling seasons (Supplementary File 1).

\section{Results}

The most abundant macrophyte species at the sampling stations were determined as Phragmites australis, Thypa latifolia, Juncus sp., and Paspalum distichum, which are primarily localized at river banks. The macrophyte plant species were observed mostly in "submerged" and "emerged" life forms. Only the species belonging to Ceratophyllum, Potamogeton, Myriophyllum, and Lemna genera were observed as floating macrophytes. The identified macrophyte plant species observed at the sampling stations are given in Table 2.

The trophic status of seven stations, representing $18.9 \%$ of all the stations, was found as "bad" in the fall season, while the stations having a bad trophic status increased to $24.3 \%$ in the spring season. In both seasons, $40.5 \%$ of the stations had poor trophic status, while
Table 2. The list of identified macrophyte plant species observed at the sampling stations, and their life forms

\begin{tabular}{|c|c|c|c|}
\hline Taxon name & $\begin{array}{l}\text { Life } \\
\text { form }\end{array}$ & Taxon name & $\begin{array}{l}\text { Life } \\
\text { form }\end{array}$ \\
\hline Agrostis stolonifera & $A$ & Myriophyllum spicatum & SM \\
\hline Alisma plantago-aquatica & SM-E & Nasturtium officinale & SM \\
\hline Apium nodiflorum & E & Myriophyllum spicatum & SM-F \\
\hline Berula erecta & $E$ & Paspalum distichum & SM-E \\
\hline Callitriche stagnalis & SM & Phragmites australis & $\mathrm{E}$ \\
\hline Carex cyperoides & $E$ & Plantago lanceolata & $A$ \\
\hline Carex flacca & $\mathrm{E}-\mathrm{A}$ & Plantago major & $A$ \\
\hline Carex paniculata & $\mathrm{E}$ & Persicaria hydropiper & $\mathrm{E}$ \\
\hline Catabrosa aquatica & $\mathrm{E}$ & Persicaria maculosa & A \\
\hline Ceratophyllum demersum & SM-F & Potamogeton crispus & SM-F \\
\hline $\begin{array}{l}\text { Ceratophyllum } \\
\text { submersum }\end{array}$ & SM-F & Potamogeton nodosus & SM-F \\
\hline Cyperus longus & $\mathrm{E}$ & Ranunculus aquatilis & SM-E \\
\hline Eleocharis palustris & SM-E & Ranunculus trichophyllus & SM-E \\
\hline Iris pseudacorus & SM-E & Rumex crispus & A \\
\hline Juncus acutus & E & Rumex hydrolapathum & E \\
\hline Juncus bulbosus & $\mathrm{E}$ & Sagittaria sagittifolia & SM \\
\hline Juncus conglomeratus & $\mathrm{E}$ & Schoenoplectus lacustris & SM \\
\hline Juncus inflexus & $\mathrm{E}$ & Typha latifolia & $E$ \\
\hline Juncus effusus & E & Typha minima & E \\
\hline Lemna minor & $\mathrm{F}$ & $\begin{array}{l}\text { Veronica } \\
\text { anagallis-aquatica }\end{array}$ & $\mathrm{E}$ \\
\hline Mentha aquatica & SM-E & Veronica beccabunga & $E$ \\
\hline
\end{tabular}

A: Amphibious, E: Emerged, F: Floating, SM: Submerged.

$21.6 \%$ of the stations were found with moderate trophic status in the same sampling period. In the fall, $13.5 \%$ of stations were found with a good trophic status, while this number decreased to $10.8 \%$ in the spring season (Table 3).

In the fall, the highest species richness (7 species) was found in 4 stations, while the lowest ( 3 species) was observed in 13 stations. On the other hand, in the spring, the highest species richness (10 species) was found in 4 stations, while 7 stations had the lowest (7 species). In general, macrophyte richness increased in the spring season (Table 3).

The $\mathrm{pH}$ values of water in the sampling stations varied between 8.18 and 9.62 in the fall season. However, these values were found between 7.18 and 8.75 in the spring season (Table 3 ). Therefore, a remarkable decrease was found in the $\mathrm{pH}$ values between the sampling seasons. 
Table 3. Season-based IBMR values and physicochemical parameters of the sampling stations

\begin{tabular}{|c|c|c|c|c|c|c|c|c|c|c|c|c|}
\hline \multirow{2}{*}{ Station } & \multicolumn{12}{|c|}{ Parameters } \\
\hline & IBMR-F & IBMR-S & Sp-F & Sp-S & $\mathrm{pH}-\mathrm{F}$ & $\mathrm{pH}-\mathrm{S}$ & $\mathrm{Fr}-\mathrm{F}$ & Fr-S & Co-F & Co-S & DO-F & DO-S \\
\hline S1 & 12.207 & 7.200 & 3 & 6 & 8.56 & 7.94 & 10.80 & 5.84 & 752 & 1092 & 10.10 & 6.19 \\
\hline$S 2$ & 7.789 & 8.750 & 3 & 3 & 8.52 & 7.84 & 11.90 & 5.81 & 770 & 1100 & 8.54 & 8.65 \\
\hline S3 & 10.207 & 9.000 & 3 & 4 & 8.67 & 8.00 & 0.00 & 0.00 & 806 & 1395 & 9.29 & 11.15 \\
\hline S4 & 9.463 & 8.370 & 6 & 10 & 8.23 & 7.22 & 0.78 & 1.40 & 350 & 311 & 6.74 & 4.18 \\
\hline S5 & 13.273 & 9.333 & 3 & 5 & 8.56 & 8.21 & 1.49 & 0.72 & 734 & 1065 & 9.39 & 8.91 \\
\hline S6 & 11.000 & 10.560 & 3 & 4 & 8.69 & 8.39 & 0.24 & 1.23 & 684 & 532 & 8.55 & 8.98 \\
\hline S7 & 9.209 & 7.385 & 4 & 6 & 8.25 & 8.44 & 0.00 & 0.00 & 917 & 1037 & 1.62 & 9.18 \\
\hline S8 & 10.585 & 7.800 & 4 & 8 & 8.33 & 7.71 & 0.00 & 0.00 & 1538 & 593 & 2.39 & 3.75 \\
\hline S9 & 7.774 & 9.515 & 6 & 10 & 8.46 & 8.16 & 1.77 & 0.00 & 627 & 405 & 8.56 & 8.66 \\
\hline S10 & 8.340 & 10.129 & 5 & 8 & 8.55 & 7.18 & 34.50 & 17.60 & 882 & 818 & 9.65 & 8.46 \\
\hline s11 & 9.077 & 11.789 & 6 & 10 & 8.86 & 8.10 & 1.13 & 20.10 & 735 & 346 & 10.82 & 10.15 \\
\hline s12 & 9.852 & 11.440 & 7 & 7 & 8.39 & 8.02 & 7.23 & 55.90 & 844 & 540 & 8.23 & 8.84 \\
\hline S13 & 9.867 & 9.150 & 6 & 8 & 8.68 & 8.35 & 0.00 & 0.00 & 459 & 489 & 11.67 & 10.0 \\
\hline S14 & 7.900 & 8.769 & 4 & 3 & 8.84 & 8.10 & 0.28 & 0.57 & 638 & 550 & 10.34 & 1.7 \\
\hline S15 & 10.167 & 9.097 & 6 & 4 & 8.26 & 7.70 & 14.80 & 18.00 & 1438 & 1426 & 1.10 & 2.17 \\
\hline S16 & 12.385 & 12.300 & 3 & 3 & 8.82 & 8.06 & 12.60 & 5.10 & 990 & 2059 & 9.89 & 5.96 \\
\hline s17 & 7.667 & 8.087 & 4 & 3 & 9.62 & 7.90 & 4.64 & 4.64 & 1535 & 1397 & 0.75 & 0.56 \\
\hline S18 & 7.824 & 6.692 & 5 & 7 & 8.70 & 8.70 & 0.00 & 0.00 & 378 & 378 & 12.21 & 12.21 \\
\hline S19 & 8.600 & 9.382 & 7 & 7 & 8.90 & 7.92 & 0.37 & 0.39 & 467 & 466 & 12.14 & 7.28 \\
\hline$S 20$ & 9.250 & 9.214 & 3 & 3 & 8.19 & 7.90 & 0.27 & 0.42 & 890 & 1061 & 9.66 & 3.88 \\
\hline$S 21$ & 11.500 & 12.818 & 5 & 4 & 8.26 & 8.08 & 0.30 & 1.92 & 508 & 481 & 7.24 & 9.12 \\
\hline$S 22$ & 8.909 & 8.545 & 4 & 4 & 8.18 & 7.69 & 2.39 & 4.48 & 583 & 592 & 1.58 & 3.50 \\
\hline$S 23$ & 11.039 & 8.000 & 3 & 9 & 8.57 & 8.05 & 5.48 & 2.40 & 691 & 910 & 8.94 & 8.06 \\
\hline$S 24$ & 12.125 & 10.738 & 7 & 5 & 8.87 & 7.47 & 0.31 & 2.09 & 144 & 300 & 11.86 & 9.56 \\
\hline$S 25$ & 13.633 & 13.000 & 7 & 6 & 8.94 & 8.45 & 0.03 & 0.03 & 478 & 510 & 10.58 & 8.91 \\
\hline$S 26$ & 9.222 & 10.962 & 4 & 3 & 8.76 & 8.14 & 0.54 & 0.49 & 443 & 495 & 9.13 & 8.58 \\
\hline$S 27$ & 14.039 & 12.316 & 5 & 6 & 8.94 & 8.46 & 4.33 & 4.16 & 904 & 412 & 12.40 & 9.25 \\
\hline$S 28$ & 10.250 & 11.091 & 3 & 3 & 8.54 & 8.40 & 0.00 & 0.03 & 199 & 289 & 11.32 & 7.90 \\
\hline$S 29$ & 10.034 & 9.250 & 7 & 5 & 8.59 & 8.36 & 0.00 & 9.34 & 400 & 359 & 9.80 & 9.75 \\
\hline 530 & 8.865 & 6.500 & 3 & 8 & 8.79 & 7.82 & 3.43 & 9.34 & 830 & 764 & 7.97 & 5.00 \\
\hline S31 & 14.400 & 8.700 & 3 & 4 & 9.01 & 8.75 & 0.00 & 0.22 & 144 & 180 & 12.32 & 8.29 \\
\hline S32 & 9.794 & 11.636 & 6 & 10 & 8.74 & 8.10 & 0.19 & 0.21 & 444 & 417 & 10.34 & 8.79 \\
\hline S33 & 9.481 & 7.314 & 6 & 9 & 8.27 & 8.27 & 0.63 & 29.30 & 685 & 685 & 4.25 & 4.25 \\
\hline S34 & 8.556 & 6.000 & 3 & 5 & 9.16 & 8.21 & 0.72 & 7.80 & 265 & 141 & 11.71 & 10.26 \\
\hline S35 & 7.667 & 7.043 & 4 & 6 & 9.08 & 7.99 & 0.00 & 7.35 & 375 & 183 & 12.86 & 10.08 \\
\hline S36 & 6.714 & 7.765 & 3 & 4 & 8.44 & 8.02 & 0.55 & 5.03 & 836 & 445 & 8.18 & 8.56 \\
\hline S37 & 9.018 & 8.522 & 4 & 8 & 8.49 & 8.19 & 0.84 & 18.90 & 802 & 404 & 9.75 & 9.13 \\
\hline MEAN & 9.937 & 9.302 & 4.5 & 5.9 & 8.64 & 8.06 & 3.31 & 6.51 & 680 & 666 & 8.70 & 7.56 \\
\hline
\end{tabular}

S: Spring, F: Fall, Sp: Number of species, Fr: Flow rate $\left(\mathrm{m}^{3} \mathrm{~s}^{-1}\right)$, Co: Conductivity $\left(\mu \mathrm{S} \mathrm{m}^{-1}\right)$, DO: Dissolved oxygen $\left(\mathrm{mg} \mathrm{L}^{-1}\right)$. 
The highest water flow rate values increased to $34.5 \mathrm{~m}^{3} \mathrm{~s}^{-1}$ and $55.9 \mathrm{~m}^{3} \mathrm{~s}^{-1}$ in the fall and spring seasons, respectively, whereas stagnant water was observed in 9 stations in fall and 6 stations in the spring season (Table 3).

The water bodies' electrical conductivity in the stations was found between 144 and $1538 \mu \mathrm{S} \mathrm{cm}^{-1}$ in the fall season. However, the electrical conductivity value varied between 141 and $2059 \mu \mathrm{S} \mathrm{cm}^{-1}$ in the spring season (Table 3). The most striking change in the electrical conductivity values was found from the $\mathrm{S} 16$ station. In the S16 station, the conductivity value was almost doubled in the spring season, while a decrease of $61.3 \%$ was found in the S8 station.

The highest dissolved oxygen concentration in the fall season was measured as $12.86 \mathrm{mg} \mathrm{L}^{-1}$ in the S35 station, while the maximum value for this parameter was found as $12.21 \mathrm{mg} \mathrm{L}^{-1}$ in the S18 station (Table 3). The dissolved oxygen levels were below hypoxic levels $\left(<3 \mathrm{mg} \mathrm{L}^{-1}\right)$ in S5 and S3 stations during the fall and spring seasons, respectively. The minimum dissolved oxygen concentrations were recorded as 0.56 and $0.75 \mathrm{mg} \mathrm{L}^{-1}$. In the S14 station, the dissolved oxygen concentration decreased by $83.2 \%$ in the spring season, while the same parameter increased 5.67-fold in the S7 station (Table 3). A positive correlation $(\mathrm{r}=0.45)$ between the $\mathrm{pH}$ and dissolved oxygen levels was found from the mean values. However, mean $\mathrm{pH}$ values were negatively correlated $(\mathrm{r}=-0.33)$ with the mean flow rate levels. Another negative correlation $(r=-0.60)$ between mean conductivity and dissolved oxygen values was found (Table 4).

Table 4. Pearson correlation coefficient (r) values
between the mean values of the parameters
investigated
\begin{tabular}{l|c|c|c|c|c|c}
\hline Parameters & IBMR & $\mathrm{Sp}$ & $\mathrm{pH}$ & $\mathrm{Fr}$ & $\mathrm{Co}$ & Do \\
\hline IBMR & & 0.11 & 0.17 & -0.24 & -0.22 & 0.25 \\
\hline Sp & & & -0.18 & -0.23 & -0.29 & 0.12 \\
\hline$p H$ & & & & $-0.33^{*}$ & -0.24 & $0.45^{* *}$ \\
\hline Fr & & & & & 0.29 & -0.14 \\
\hline Co & & & & & & $-0.60^{* *}$ \\
\hline DO & & & & & & \\
\hline
\end{tabular}

The asterisks indicate the significant correlations at the $0.05^{*}$ and $0.01^{* *}$ levels.

\section{Discussion}

The data collected in the present study were used to evaluate the trophy levels and some physicochemical parameters of watercourses throughout the Sakarya River Basin of Turkey. In previous reports, trophy statues and qualities of some standing water bodies have been evaluated in the Sakarya River Basin (Burnak and Beklioğlu,
2000; Karakoç et al., 2003; Muhammetoglu et al., 2005; Akin et al., 2011; Akkoyunlu and Ekiner, 2012). However, most of these studies evaluated chemical data and did not implement a model based on macrophytes. The IBMR is based on three metrics: field cover percentage, the species trophic score, and a coefficient of ecological amplitude that measures the variety of habitats in which a species can survive (Wiederkehr et al., 2015). Thus, IBMR is solely based on the abundance and diversity of macrophyte species, and it is considered as an useful index to evaluate the ecological status of running water affected by nutrient input or organic pollutants (Haury et al., 2006). Nevertheless, IBMR data should be supported with analyses of hydro-chemical data obtained from environmental monitoring (Marzin et al., 2012). Some macrophyte species such as Typha latifolia and Phragmites australis have been reported as indicators of water quality and contamination (Bonnano and Giudice, 2010; Klink et al., 2013). On the other hand, IBMR presents not a single-species-based evaluation of the ecological quality assessment method, but represents a holistic approach to the environment assessed by covering all the water-related macro plant species.

The primary factor that causes water eutrophication is considered to be excessive phosphorus $(\mathrm{P})$ and nitrogen $(\mathrm{N})$ input into the water system, since these elements regulate primary production (Yang et al., 2008). However, Dauvin et al. (2007) stated that it might be more connected to $\mathrm{P}$ and N's imbalanced loading into the water concerning silicon dioxide $\left(\mathrm{SiO}_{2}\right)$. A drop in dissolved silica availability reduces the development of diatoms, whereas in this case, non-siliceous organisms increase, likely leading to unwanted eutrophication (Amann, 2014). An eutrophicated water system shows symptoms such as algal blooms, oxygen deficiency, and increased sedimentation (Rydin et al., 2017). Algal blooms are seen more commonly in lakes, ponds, or sea since they have low turbidity and flow, presenting a favorable condition for algal growth. Although no algal blooms were observed in the sampling stations during the present study, the sampled stations with IBMR values of less than 8 are hypertrophic. However, seasonal changes in the macrophyte abundance and composition should be taken into account when deciding the station's final trophy level. Therefore, the stations having IBMR values less than 8 in both sampling seasons (S18, S35, and S36) of our study were considered hypertrophic. On the other hand, considering the mean IBMR values of its running waters (9.937 in the fall and 9.302 in the spring seasons, $\mathrm{n}=37$ ), the general trophy level of the Sakarya River Basin should be evaluated as eutrophic. In a study conducted for the evolution of the aquatic vegetation and ecological status of the Semois-Chiers Basin in Belgium, the researchers reported that physicochemical properties and anthropogenic pressure play a significant 
role in macrophyte distribution among the stations, especially of resistant species, thereby leading to the variations in the IBMR values (Khadija et al., 2015). In this context, it should be noted that a high IBMR value is not thoroughly associated with a high number of species sampled, but it is related to the CSi scores of these species. In our study, the Pearson correlation between IBMR values and species number were insignificant $(\mathrm{P}>0.05$, $\mathrm{n}=37$ ) for both seasons. The low IBMR values in the presence of a high number of species can be explained by macrophyte species' associations with low CSi scores, since a low CSi score indicates heavy organic pollution and heterotrophic species. In contrast, high CSi values indicate oligotrophic species susceptible to the factors mentioned above (Haury et al., 2006).

The lack of dissolved oxygen in the water, which is an unfavorable condition for aquatic fauna elements, can be one of the consequences of eutrophication (Coffin et al., 2018). In the present study, the dissolved oxygen concentrations were below hypoxia level $\left(<3 \mathrm{mg} \mathrm{L}^{-1}\right)$ in the stations S7, S8, S14, S15, S17, and S22 at least in one season. Also, the eutrophic and/or hypertrophic conditions were accompanied by hypoxia in all these stations except S8. The stations S7 (Gökçekaya Stream, NallıhanAnkara), S14 (Pürlek Creek, Sivrihisar-Eskişehir), and S15 (Ankara Stream, Polatl1-Ankara) are located close to agricultural areas. Also, the station S8 (Karadere Creek, Yenişehir District, Bursa) is located close to a populated city center, and the stations S17 (Ankara Stream, SincanAnkara) and S22 (Porsuk Stream, City Center-Kütahya) are located near industrial areas. According to the field observations, the waters in these stations were not clear, which might indicate possible contamination. However, this observation should be validated through analytical experiments. Although some plant species can adapt to oxygen deprivation through various mechanisms such as metabolic rate decrement and removal of toxic anaerobic products, to be exposed to hypoxic conditions for a long time could bring irreversible breakdowns in biodiversity (Chirkova and Yemelyanov, 2018). Therefore, suitable wastewater treatment should be considered around these localities if water contamination is found in future studies. The remarkable seasonal variation between dissolved oxygen concentrations measured, e.g., in S7 (1.62 and $9.18 \mathrm{mg} \mathrm{L}^{-1}$ in fall and spring, respectively), and S14 (10.34 and $1.7 \mathrm{mg} \mathrm{L}^{-1}$ in fall and spring, respectively) could be attributed to changes in weather conditions (e.g., winds and rainfall). Besides dissolved oxygen, water $\mathrm{pH}$ and conductivity may play a key role in eutrophication. The $\mathrm{pH}$ of river water can be affected by the ground's mineralogical content consisting of different substratum types (Mihu-Pintilie et al., 2014). However, a more significant contribution to $\mathrm{pH}$ change might originate from the effluents of various sources (Morrison et al., 2001). A change in $\mathrm{pH}$ can influence floral composition (Palagushkina et al., 2019), ionization of electrolytes, dissolved silica uptake by diatoms, and higher plants; accordingly it can influence the trophic status of the ecosystem by promoting undesirable organisms' proliferation (Yang et al., 2008; Amann et al., 2014). Furthermore, a change in the $\mathrm{pH}$ would directly affect the macrophyte abundance and composition in the rivers (Reitsema et al., 2018). The conductivity of water can be affected by temperature, pollution, and organic materials. Therefore, increased conductivity in the sampling stations might signal the external input of organic nutrients to the river. In a study conducted at the Ceyhan River Basin located in Turkey's southern Anatolia, 33 macrophyte taxa were observed, and the researchers evaluated the ecological status of the Ceyhan River Basin from moderate to bad, which shows similarities to the Sakarya River Basin's status (Özbay et al., 2019). In a study conducted on the lakes of Balkan countries such as Albania, North Macedonia, Montenegro, and Serbia, where the researchers analyzed submerged aquatic vegetation, water chemistry, and sediment total phosphorus content, it was found that macrophyte indices such as the BMI (Balkan Macrophyte Index) may not be valid in lakes with annual variations in water levels, because macrophyte vegetation in such lakes may be absent or dominated by oligotrophic or eutrophic plants (Schneider et al., 2020). Other research performed on bryophyte and macrophyte species of Bulgarian rivers found that bryophyte populations were affected mostly by the velocity of water flow, while shading was the most significant factor determining the vascular plant composition at the sampling sites. The researchers reported that an increase in the number of sampled macrophytes occurs with decreasing shading gradient; therefore, riverside vegetation along lowland rivers can prevent macrophyte growth (Gecheva et al., 2013). Therefore, countries should consider building their macrophyte indexes optimized according to their rivers' and lakes' physicochemical and biotic status to ensure reliable ecological monitoring and assessment.

\section{Conclusions}

Numerous environmental factors affect the Sakarya River's water quality, since it is one of the largest basins in Turkey. Therefore, practical tools and a holistic approach, including physicochemical parameters and several ecological quality metrics applied to other living components of the freshwaters, should be employed to screen the Sakarya River Basin's environmental quality. Therefore, to enable a complete screening of ecological quality, phytobenthos and water-related fauna should be taken into consideration and simultaneously evaluated with macrophytes and physicochemical data. The domestic, industrial, and agricultural discharge points 
on the basin should be strictly controlled. The present study results would be useful for applying conservation measures on the basin and fulfilling the regulation of the Water Framework Directive (WFD).

\section{Acknowledgments}

The authors wish to thank the General Directorate of State Hydraulic Works Investigating, Planning and Allocations Department, Environmental Section Managers, Kocaeli University Hydrobiology R\&D Laboratory staff for their valuable support during the sampling and analysis procedure.

\section{References}

AFNOR. 2003. Qualité de l'eau: Détermination de l'indice biologique macrophytique en rivière (IBMR). NF T90-395.

Akin, B. S., Atıcı, T., Katircioglu, H., and Keskin, F. 2011. Investigation of water quality on Gökçekaya Dam Lake using multivariate statistical analysis, in Eskişehir, Turkey. Environmental Earth Sciences 63(6):1251-1261. https://doi. org/10.1007/s12665-010-0798-6

Akkoyunlu, A. and Akiner, M. E. 2012. Pollution evaluation in streams using water quality indices: A case study from Turkey's Sapanca Lake Basin. Ecological Indicators 18:501511. https://doi.org/10.1016/j.ecolind.2011.12.018

Amann, T., Weiss, A., and Hartmann, J. 2014. Silica fluxes in the inner Elbe Estuary, Germany. Biogeochemistry 118:389412. https://doi.org/10.1007/s10533-013-9940-3

Bonnano, G. and Lo Giudice, R. 2010. Heavy metal bioaccumulation by the organs of Phragmites australis (common reed) and their potential use as contamination indicators. Ecological Indicators 10(3):639-645. https://doi. org/10.1016/j.ecolind.2009.11.002

Burnak, S. L. and Beklioğlu, M. 2000. Macrophyte-dominated clearwater state of Lake Mogan. Turkish Journal of Zoology 24:305-313.

Ceschin, S., Zuccarello, V., and Caneva, G. 2010. Role of macrophyte communities as bioindicators of water quality: Application on the Tiber River basin (Italy). Plant Biosystems 144(3):528-536. https://doi. org/10.1080/11263500903429221

Chirkova, T. and Yemelyanov, V. 2018. The study of plant adaptation to oxygen deficiency in Saint Petersburg University. Biological Communications 63(1):17-31. https:// doi.org/10.21638/spbu03.2018.104

Chislock, M. F., Doster, E., Zitomer, R. A., and Wilson, A. E. 2013. Eutrophication: causes, consequences, and controls in aquatic ecosystems. Nature Education Knowledge 4(4):10.

Coffin, M.R.S., Courtenay, S. C., Pater, C. C., and van den Heuvel, M. R. 2018. An empirical model using dissolved oxygen as an indicator for eutrophication at a regional scale. Marine Pollution Bulletin 133:261-270. https://doi. org/10.1016/j.marpolbul.2018.05.041

Cook, C. D. K., Gut, B. J., Rix, E. M., and Schneller, J. 1974. Water plants of the World: A manual for the identification of the genera of freshwater macrophytes, Dr. W. Junk b.v., Publishers, The Hague.

Dauvin, J. C., Ruellet, T., Desroy, N., and Janson, A. L. 2007. The ecological quality status of the Bay of Seine and the Seine estuary: Use of biotic indices. Marine Pollution Bulletin 55:241-257. https://doi.org/10.1016/j.marpolbul.2006.04.010

Davis, P. H. 1985. Flora of Turkey and the East Aegean Islands, vol. IX, Edinburgh University Press, Edinburgh.

Dawson, F. H., Newman. J. R., and Gravelle, M.J. 1996. Mean trophic rank macrophyte survey. An assessment of the trophic status of rivers using macrophytes. Research \& Development, Interim Report 694/NW/01. Environment Agency, Bristol, $29 \mathrm{pp}$.

DSi (General Directorate of Water Management, Republic of Turkey Ministry of Food Agriculture and Livestock). 2016. Effect of climate change on water resources project final report, Appendix 14.

Elo, M., Alahuhta, J., Kanninen, A., Meissner, K. K., Seppälä, K., and Mönkkönen, M. 2018. Environmental characteristics and anthropogenic impact jointly modify aquatic macrophyte species diversity. Frontiers in Plant Science 9:1001. https://doi.org/10.3389/fpls.2018.01001

European Council. 2000. Directive 2000/60/EC of the European Parliament and of the Council of 23 October 2000 establishing a framework for Community action in the field of water policy. Official Journal, L 327, 22/12/2000 P. 0001-0073.

Gecheva, G., Yurukova, L., and Cheshmedjiev, S. 2013. Patterns of aquatic macrophyte species composition and distribution in Bulgarian rivers. Turkish Journal of Botany 37:99-110. https://doi.org/10.3906/bot-1112-35

Haury, J., Peltre, M-C., Trémolières, M., Barbe, J., Thiébaut, G., Bernez, I., Daniel, H., Chatenet, P., Haan-Archipof, G., Muller, S., Dutartre, A., Laplace-Treyture, C., Cazaubon, A., and Lambert-Servien, E. 2006. A new method to assess water trophy and organic pollution - the Macrophyte Biological Index for Rivers (IBMR): its application to different types of river and pollution. Hydrobiologia 570:153-158. https://doi.org/10.1007/s10750-006-0175-3

Karakoç, G., Erkoç, F. Ü., and Katırcıoğlu, H. 2003. Water quality and impacts of pollution sources for Eymir and Mogan Lakes (Turkey). Environment International 29(1):21-27. https://doi.org/10.1016/s0160-4120(02)00128-9

Khadija, S-A., Francis, R., and Bernard, T. 2015. Trend analysis in ecological status and macrophytic characterization of watercourses: Case of the Semois-Chiers Basin, Belgium Wallonia. Journal of Water Resource and Protection 7(13):59391. https://doi.org/10.4236/jwarp.2015.713080

Khatri, N., and Tyagi, S. 2015. Influences of natural and anthropogenic factors on surface and groundwater quality in rural and urban areas. Frontiers in Life Science 8(1):2329. https://doi.org/10.1080/21553769.2014.933716

Klink, A., Macioł, A., Wisłocka, M., and Krawczyk, J. 2013. Metal accumulation and distribution in the organs of Typha latifolia L. (cattail) and their potential use in bioindication. Limnologica 43(3):164-168. https://doi.org/10.1016/j. limno.2012.08.012

Lopes A., Parolin P., and Piedade, M. T. F. 2016. Morphological and physiological traits of aquatic macrophytes respond to water chemistry in the Amazon Basin: an example of the genus Montrichardia Crueg (Araceae). Hydrobiologia 766:1-15. https://doi.org/10.1007/s10750-015-2431-x

Manera, M., Frattaroli, A. R., Nicolai, S., Di Sabatino, A., and Giansante, C. 2014. Macrophyte Biological Index for Rivers estimation in the waters of Pescara Springs by means of SCUBA dive and orthophotos interpretation. Ecohydrology \& Hydrobiology 14:296-303. https://doi. org/10.1016/j.ecohyd.2014.08.002

Marzin, A., Archaimbault, V., Belliard, J., Chauvin, C., Delmas, F., and Pont, D. 2012. Ecological assessment of running waters: Do macrophytes, macroinvertebrates, diatoms and fish show similar responses to human pressures? Ecological Indicators 23:56-65. https://doi. org/10.1016/j.ecolind.2012.03.010

Mihu-Pintilie, A., Romanescu, G., and Stoleriu, C. 2014. The seasonal changes of the temperature, $\mathrm{pH}$ and dissolved oxygen in the Cuejdel Lake, Romania. Carpathian Journal of Earth and Environmental Sciences 9(2):113-123. 
Morrison, G., Fatoki, O. S., Persson, L., and Ekberg, A. 2001. Assessment of the impact of point source pollution from the Keiskammahoek Sewage Treatment Plant on the Keiskamma River - $\mathrm{pH}$, electrical conductivity, oxygen- demanding substance (COD) and nutrients. Water SA 27:475-480. https://doi.org/10.4314/wsa.v27i4.4960

Muhammetoglu, A., Muhammetoglu, H., Oktas, S., Ozgokcen, L., and Soyupak, S. 2005. Impact assessment of different management scenarios on water quality of Porsuk River and Dam system - Turkey. Water Resources Management 19(2):199-210. https://doi.org/10.1007/ s11269-005-3473-z

Özbay, H., Yaprak, A. E., and Turan, N. 2019. Assessing water quality in the Ceyhan River basin (Turkey) with the use of aquatic macrophytes. Chemistry and Ecology 35(10):891902. https://doi.org/10.1080/02757540.2019.1668928

Özen, F., Acemi, A., Pelin, E. G., and Ergül, H. A. 2017. Assessment of macrophyte plant distribution and pah contamination in selected aquatic habitats from an industrialized city Kocaeli, Turkey. Biomonitoring 4:27-33. https:// doi.org/10.1515/bimo-2017-0003

Palagushkina, O., Nazarova, L., and Frolova, L. 2019. Trends in development of diatom flora from sub-recent lake sediments of the Lake Bolshoy Kharbey (Bolshezemelskaya tundra, Russia). Biological Communications 64(4):244251. https://doi.org/10.21638/spbu03.2019.403

Reitsema, R. E., Meire, P., and Schoelynck, J. 2018. The future of freshwater macrophytes in a changing world: dissolved organic carbon quantity and quality and its interactions with macrophytes. Frontiers in Plant Science 9:629. https://doi.org/10.3389/fpls.2018.00629

Rydin, E., Kumblad, L., Wulff, F., and Larsson, P. 2017. Remediation of a eutrophic bay in the Baltic Sea. Environmental Science \& Technology 51(8):4559-4566. https://doi. org/10.1021/acs.est.6b06187
Schneider, S. and Melzer, A. 2003. The trophic index of macrophytes (TIM) - A new tool for indicating the trophic state of running waters. International Review of Hydrobiology 88(1):49-67. https://doi.org/10.1002/iroh.200390005

Schneider, S. C, Trajanovska, S., Biberdžić, V., Marković, A., Talevska, M., Imeri, A., Veljanoska-Sarafiloska, E., Đurašković, P., Jovanović, K., and Cara, M. 2020. The Balkan Macrophyte Index (BMI) for assessment of eutrophication in lakes. Acta Zoologica Bulgarica 72(3):439-454.

Solak, C. N., Peszek, Ł., Yilmaz, E., Ergül, H. A., Kayal, M., Ekmekçi, F., Várbíró, G., Yüce, A. M., Canli, O., Binici, M. S., and Ács, É. 2020. Use of diatoms in monitoring the Sakarya River Basin, Turkey. Water 12:703. https://doi. org/10.3390/w12030703

Solimini, A. G., Cardoso, A. C., Carstensen, J., Free, G., Heiskanen, A-S., Jepsen, N., Nõges, P., Poikane, S., and van de Bund, W. 2008. The monitoring of ecological status of European freshwaters. In: The Water Framework Directive Ecological and Chemical Status Monitoring.

Szoszkiewicz, K., Zbierska, J., Staniszewski, R., and Jusik, S. 2009. The variability of macrophyte metrics used in river monitoring. Oceanological and Hydrobiological Studies 38(4):117-126. https://doi.org/10.2478/v10009-0090049-x

Wiederkehr, J., Grac, C., Fabrègue, M., Fontan, B., Labat, F., Le Ber, F., and Trémolières, M. 2015. Experimental study of uncertainties on the macrophyte index (IBMR) based on species identification and cover. Ecological Indicators 50:242-250. https://doi.org/10.1016/j. ecolind.2014.10.021

Yang, X-E., Wu, X., Hao, H-L., and He, Z-L. 2008. Mechanisms and assessment of water eutrophication. Journal of Zhejiang University SCIENCE B 9(3):197-209. https://doi. org/10.1631/jzus.B0710626 